\title{
TRADING IN FUTURES
}

\section{A sound investment?}

BY S. R. ALGERNON

"S o we're, like, buying a planet?" says the green-eyed kid sitting across your desk. The inquisitive eyes on their slender face drift over your shoulder to the star maps and stock tickers behind you, and settle for a moment on the model of H. G. Wells's time machine on your desk.

"Not a whole planet, Jae," says their partner. This one has bright orange hair and wears a sweatshirt with the name of a local college that has a pretty good reputation. She goes by 'she', a traditional pronoun, but she has gill mods on the sides of her neck. Her tapetum lucidum shines when it catches the light just right. "Just a small piece of one."

Kids today live life on their own terms, you think, not like it was when you were young. You nurture that thought; it helps you live with yourself.

"Not exactly," you say, leaning forward as if letting them in on a secret. "You're buying a share of a colony venture to a particular world. The colony charter mandates that a share of the colony's production be transmitted back to Earth in cryptocurrency, and as shareholders you would get a portion of that sum."

"I see", says Tabitha - geez, the one with the cat's eyes is named Tabby. Why do they always have to be so memorable?

"But, wait," says Jae, raising an index finger as they glance down at the brochure. "These exoplanet ventures take decades or centuries. How are we supposed to make money off of them now?"

Ilean forward again, but Tabby cuts me off.

"I read up on this," she says. "Five hundred years ago, in Holland, people paid vast amounts of money for tulip bulbs. It didn't matter whether they would ever see the tulip grow or not. The point is, they could sell the bulb to somebody else later for a higher price."

"You've got it figured out," I say. "As the launch date grows nearer, the prospect that the colony will succeed goes up, and your

ONATURE.COM Follow Futures: y @NatureFutures

f go.nature.com/mtoodm share of the expected profit is more valuable. If you buy in now, at the planning stage, someone else 50 years

(6)

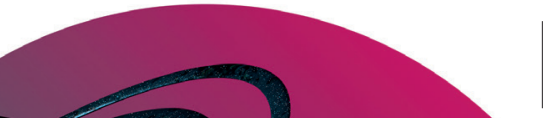

"Of course," says Tabby. The smart ones are easy marks because their imagination does the work for you.

"The Astrophants have provided geological survey data of all the planets in the system. The astronomers on our payroll will 'discover' them in dribs and drabs over the next few decades to stoke interest and drive up the share price. You get to retire, and we make quite a bit for ourselves. It's win-win."

"Hmm," said Jae. Before they can think too deeply about it, you continue. of this were to get out, people 11 $\begin{aligned} & \text { of this were to get out, people } \\ & \text { would think we were crack- }\end{aligned}$ pots, so we would appreciate it if you would keep this trade secret to yourselves."

"Sure," says Jae.

"Mmm-hm," says Tabby.

You know they'll talk, enough to bring in

from now will pay you 100 times as much once the venture is under way."

"But," says Jae, "if the venture goes bust, our share is worthless."

"Right," you say. It's nice to know they still teach introductory economics. Now, you eye Tabby with a conspiratorial glance and steeple your fingers. You can tell from the shimmer in Tabby's eye that her ocular augmentations will catch a lie.

"I can guarantee that this ship will launch, and that the shares you buy with your modest savings will be enough to fund your retirement."

"How?" asked Jae. Tabby glances at them, then back at you.

"I can only tell you that once you have skin in the game, once the transfer goes through."

That's usually where they bail, if they're going to. You speak before they can answer.

"Before you decide, let me offer you our most popular product, a futures contract. It says that 50 years from today, we will buy your shares at 75 times their current value. If it goes bust, we lose, not you."

Tabby knows you haven't lied, not really, and Jae doesn't want to leave your office with any what-ifs. They both read the contract over. Jae nods at Tabby, and she runs her wrist over your scanner. It beeps.

"All right," you say. "I keep my word, so here's the story. Our firm has been in FTL contact with another species, called the Astrophants. You know what FTL means, don't you?" new clients but not enough to provoke the regulatory agencies. You send the couple off with a smile. In the silence of your office, the story that you didn't tell creeps back into your mind.

You didn't tell them that the Astrophants disdain the grubby work of mining and prefer to leave it to lesser races. You didn't mention the jamming field and automated labour camp that await the colonists. You tell yourself that you've harmed no one. The colonists aren't even born yet. You tell yourself that when they set off, they will do so of their own free will.

When that doesn't work, you remind yourself that the Astrophants disdain mining, but they do quite enjoy conquest when tribute is not paid to their satisfaction.

You glance down at Wells's machine. That book was never about time, after all. It was about something timeless in humanity. By serving the Eloi of your age, you create the next generation of Morlocks. And thus the human race endures, still nasty and brutish, but no longer alone.

For now, you file the contract away, take a drink, and wait for the next knock on your office door.

S. R. Algernon studied fiction writing and biology, among other things, at the University of North Carolina at Chapel Hill. He currently lives in Michigan. 